\section{The effect of hydrophilic gel from the second layer of Tingui (Magonia pubescens St. Hil.) seeds on germination and early development of cucumber (Cucumis sativus L.)}

\author{
O efeito do gel hidrofílico da segunda camada de sementes da Tingui \\ (Magonia pubescens St. Hil) na germinação e no desenvolvimento inicial \\ de pepino (Cucumis sativus $L$.)
}

Matheus Couto Alves ${ }^{[a]}$, Antonio Zenon Antunes Teixeira ${ }^{[b]}$

\begin{abstract}
Some plant species from Cerrado were considered to have allelopathic effects. Allelopathy means the chemical competition between plants wich can benefit or harm another plant. The objective of this study was to determine the effect of hydrophilic gel from the second layer of Magonia pubescens St. Hil. seeds (a high plant, known as Tingui, that grows in the areas of (errado) on germination and early development of cucumber (Cucumis sativus L.). The cucumber seeds were treated with a mixture of sand and powder of Tingui in different proportions of $25 \%, 50 \%, 75 \%$ and $100 \%$. The sand was previously washed with tap water, then with distilled water and, after that, it was dried in an oven at $100 \mathrm{oC}$ for 5 hours. The seeds were planted in $50 \mathrm{ml}$ polystyerenes cups and moistened with water daily. To check possible changes from the process, a batch of seed were tested under the same conditions without the Tingui powder (only with sand). The parameters of this study were to measure the seed germination and plant development. The growth period was seven days, under $\pm 30^{\circ} \mathrm{C}$, and 12 hours photoperiod. The overall data were analyzed using ANOVA and Scheffe test, at $5 \%$ significance level. From the results, we concluded that there were no differences in the percentage of seed germination for all treatments, except the treatment of $100 \%$. As for the germination average time and the seed growth, there were no significant differences between the treatment of $25 \%$ and the control, but the effects were more effective at higher concentrations.
\end{abstract}

Palavras-chave: Germination. Hydrophilic gel. Magonia pubescens St. Hil.

\section{Resumo}

Algumas espécies de plantas do Cerrado foram examinadas como tendo efeitos alelopáticos. Alelopatia significa a competição química entre plantas, a qual pode ocorrer para beneficiar ou prejudicar outra planta. 0 objetivo do presente trabalho foi determinar o efeito do gel hidrofilico de segunda camada das sementes da Magonia pubescens St. Hil. (Tingui) na germinação e no desenvolvimento inicial do pepino (Cucumis sativus L.), para gerar as possivivis concentrações para um estudo no processo de peletização de sementes. As sementes foram tratadas com uma mistura de areia e pó de Tingui, em vários proporções, de 25\%, 50\%, 75\% e 100\%. A areia foi lavada previamente com água da torneira e, em seguida, com água destilada, sendo, depois, seca em estufa a 1000 C, durante 5 horas. As sementes foram plantadas em copos de poliestireno de $50 \mathrm{ml}$ e umedecidas com água diariamente. Para verificar possíveis alterações decorrentes do processo, foram testados, nas mesmas condições, lotes de sementes sem o pó da semente da Tingui (só com areia). Os parâmetros deste estudo foram mediar o germinativo de sementes e o desenvolvimento das plantas. 0 tempo de crescimento foi de sete dias, $a \pm 30^{\circ} \mathrm{C}$, e fotoperíodo de 12 horas. Os dados foram analisados utilizando-se o módulo de análise de variância (ANOVA) e o teste de Scheffe, a 5\% de significância. Pelos resultados, pode-se concluir que não houve diferença em relação à porcentagem de germinação das sementes por todos os tratamentos, exceto o tratamento de 100\%. Em relação ao tempo médio de germinação e ao crescimento de semente, não se apresentou diferença significativa entre o tratamento de $25 \%$ e o controle, mas o efeito foi mais efetivo nas concentrações mais elevadas.

Keywords: Gel Hidrofilico. Germinação. Magonia pubescens St. Hil. [a] Graduation in Chemistry, PIBIC scientific initiation student, register n. PIBITI 007-2010, IFG, Goiania, GO - Brazil

${ }^{[b]} \mathrm{PhD}$ in Biochemistry, Universidade Federal do Paraná (UFPR), IFG professor, Goiania, GO - Brazil, e-mail: antonio.teixeira@ifg.edu.br
Received: 10/14/2011

Recebido: 14/10/2011

Approved: 02/23/2012

Aprovado: 23/02/2012 


\section{Introduction}

One can claim that life is a real jungle where each creature struggles for survival. The higher plants compete with others for water, sun and fertile soil in the nature. They have built many ways to protect themselves against their surrounding plants, and when this is a chemical defense in nature, it is called allelopathy. Allelopathy means the chemical competition between plants, the effect caused by one higher plant over another one in the same ecosystem (1). The effects can benefit or harm another plant, for example, in its root or shoot development. The chemical effect can be released by exudation, volatilization, leaching or decomposition of residues (2).

The Brazilian Cerrado is an extremely complex biome that spreads over 200 million ha in Central Brazil. This biome provides a great potential for the use of its biodiversity $(3,4)$. However, it is one of the 25 places in the world that is considered critical to conservation due to the biologic wealth and the high pressure from the human occupation of the land (5). Many plant species from Cerrado were considered to have allelopathic effects which could inhibit the germination of seeds from other species and the establishment of plantlets (6). Oliveira, Ferreira and Borgetthi (2) revealed the allelopatic effect of Solanum lycocarpum leaves, a Cerrado plant known locally as Lobeira, on the average germination time and root growth of Sesamun indicum L. The leaf extract of Stryphnodendron adstringens (Mart.) Coville, widely identified as Barbatimão, presented inhibitory effects on the length of the tomato primary root (7) and the seed development of cucumber (8).

However, the finding that allelophaty can be a feasible element of crop/weed interactions stimulated the idea of exploiting this phenomenon to manage weeds (9). Similarly, the search for antimicrobial activity from natural resources has increased during the last decades. Fungi diseases are one of the causes of crops production loss, among them, Colletotrichum gossypii var. cephalosporioides (cotton), Sclerotinia sclerotiorum (soya), Fusarium solani f. sp. (soya), Macrophomina phaseolina (soya), Colletotrichum gloeosporioides (wheat) and Pyricularia grisea (rice) (10), and fungicide applications are one of the most common seed treatments that is usually applied to the seed's coat/pellet (11).

Magonia pubescens St. Hil. is a high plant that grows in the areas of Cerrado and well known as Tingui.
The seed has many layers; the second layer contains carbohydrates (12) and forms a gel when in contact with water that may be important for drought adaptation in terms of germination (13). Besides, it has antifungal properties against Penicillum, Aspergillus and Hormodendrum spp. (14). The study of Oliveira (10) revealed that the ethanol extract from the root of Magonia sp. provides antimicrobial activity against $C$. gossypii var. Cephalosporioides, M. phaseolina and P. grisea.

In addition, a comparative study between the properties of commercial ingredients commonly used for seed pelleting and the powder of Tingui confirmed its possibility to be an ingredient in the seed pelleting process. The result also showed that Tingui has properties comparable to HPMC (hydroxy propyl methyl cellulose) and PVP (polyvinyl pyrrolidone), two polymers that are widely used in seed coating. The large amount of potassium and antifungal properties of Tingui may also enhance its value as a material for seed pelleting $(15,16)$. This study aimed to determine the effects of hydrophilic gel from the second layer of Magonia pubescens St. Hil. seeds on germination and early development of cucumber (Cucumis sativus L.). The study is based on the interest of finding the possible Tingui concentration that can be applied for seed pelleting.

Cucumber is one of the plant species most recommended by the U.S. Environmental Protection Agency (17), the Food and Drug Administration U.S. (18) and the Organization for Economic Cooperation and Development (19) for seed germination and roots/ shoots developments (20).

\section{Materials and methods}

\section{Seed characteristics}

The seeds used in this study were cucumbers (Cucumis sativus L.), produced by Isla, lot number 30032 , 95\% germination and $100 \%$ purity, analyzed by Isla Company on $11 / 11 / 2010$, with three years expired time.

To characterize the size of the seeds used in this experiment, they were taken randomly and weighed on an analytical scale accurate to $0.1 \mathrm{mg}$. The random samples show that the average weight of the seeds was $2.09 \mathrm{mg}$ with a standard deviation of 0.40 mg (Table 1). 
Tabela 1 - Weight variation in random samples of Cucumis sativus L. seeds

\begin{tabular}{cccccc}
\hline Sample & Weight $(\mathrm{mg})$ & Sample & Weight $(\mathrm{mg})$ & Sample & Weight \\
\hline 1 & 2,09 & 5 & 2,92 & 9 & 1,93 \\
2 & 1,98 & 6 & 1,75 & 10 & 1,96 \\
3 & 1,70 & 7 & 1,95 & 11 & 1,77 \\
4 & 2,70 & 8 & 1,87 & 12 & 2,45 \\
\hline
\end{tabular}

Source: Research data

\section{Seed germination}

The effects of hydrophilic gel were tested in three repetitions of 25 cucumber seeds. The powder-forming gel was obtained from the second layer of ripe seeds of Magonia pubescens St. Hil. The seeds were treated with 2 grams of a mixture of sand and Tingui powder, in various concentrations of Tingui: $25 \%, 50 \%, 75 \%, 100 \%$ and $0 \%$ (only sand) as a control. The sand with grain size from 0.30 to $0.35 \mathrm{~mm}$ was previously washed with tap water, then washed with distilled water and dried in an oven at $100^{\circ} \mathrm{C}$ for 5 hours. All treated cucumber seeds were planted in $50 \mathrm{ml}$ polystyrenes cups and moistened with water daily. When the treatments were watered, the powder turned into gel. The growth period was seven days under \pm $30{ }^{\circ} \mathrm{C}$ and 12 hours photoperiod. The germination rate was counted when the chlorophyll in cucumber cotyledons appeared and it was checked every 24 hours. The germination rate was expressed as a percentage, germination average time was count in days and seed growth was expressed in centimeters.

\section{Statistical analysis}

The effects of the various treatments were evaluated statically using analysis of variance (ANOVA), and the means were compared by Scheffe test at $5 \%$ significance level.

\section{Results and discussion}

\section{Germination}

The cucumber seeds germination rate showed no significant differences when treated with Magonia pubescens St. Hil. gel at 25, 50 and 75\% concentrations (Table 2). However, the treated seeds with $100 \%$ concentration significantly reduced the percentage of germination.

The results obtained by Joly, Felippe, Dietrich and Campos-Takaki (13) also confirmed that the filtered gel of Magonia pubescens St. Hil. showed no effect in promoting Cucumis anguria and Rumex obtusifolius germination. In this experiment, the gel was used at the concentrations of $0.004,0.4$ and $4.0 \mathrm{mg} / \mathrm{ml}$.

Tabela 2 - Germination rate of Cucumis sativus L. at various concentrations of Tingui hydrophilic gel

\begin{tabular}{cc}
\hline Concentration of Magonia pubescens St. Hil. (\%) & Germination (\%) \\
\hline $0 \%$ (Control) & 83 \\
$25 \%$ & 83 \\
$50 \%$ & 93 \\
$75 \%$ & 87 \\
$100 \%$ & 63 \\
\hline
\end{tabular}

Source: Research data

Estud Biol. 2012 jan/abr;34(82):61-66 
Tabela 3 - Average time of Cucumis sativus L. seed germination in various concentrations of Tingui hydrophilic gel

\begin{tabular}{cc}
\hline & \\
Concentration of Magonia pubescens St. Hil. (\%) & Time (days) \\
\hline $0 \%$ (Control) & 3,3 \\
$25 \%$ & 3,4 \\
$50 \%$ & 4,5 \\
$75 \%$ & 5,4 \\
$100 \%$ & 5,6 \\
\hline
\end{tabular}

Source: Research data

Tabela 4 - Average length of Cucumis sativus L. shoot seeds submitted in Tingui hydrophilic gel at different concentrations

\begin{tabular}{cc}
\hline Concentration of Magonia pubescens St. Hil. (\%) & Shoot length $(\mathbf{c m})$ \\
\hline $0 \%$ (Control) & $7,81 \pm 1,85^{\mathrm{a}}$ \\
$25 \%$ & $6,95 \pm 1,47^{\mathrm{a}}$ \\
$50 \%$ & $3,96 \pm 0,92$ \\
$75 \%$ & $1,17 \pm 0,84^{\mathrm{b}}$ \\
$100 \%$ & $0,79 \pm 0,30^{\mathrm{b}}$ \\
\hline
\end{tabular}

Note: ${ }^{[a]}$ and ${ }^{[b]}$ means no significant differences according to Scheffe test at $5 \%$.

Source: Research data

We also observed the effect of the gel from Tingui powder in relation to the germination process average time. Still, according to Joly, Felippe, Dietrich and Campos-Takaki (13), this gel retards the germination process speed, but does not affect the final germination number. Table 3 shows that the average germination time for the seeds treated at $25 \%$ was 3,4 days, while the treatment at $50 \%$ was 4,5 days. The average germination time increased when the seed concentration increased (Table 3). This occurred because the gel formed during imbibition slowed the germination process by using some of the water destined for the embryo.

\section{Seed development}

Regarding to the seedling growth, Table 4 and Figure 2 reveal that the treatment at 25\% demonstrated faster seed development in comparison to the treated seeds at 50, 75 and $100 \%$ concentrations. As for the control, there was no significant difference between the shoot lengths, $6.95 \mathrm{~cm}$ for the seed treated at $25 \%$ and $7.81 \mathrm{~cm}$ for the control.

The results also show that increasing the concentration of Magonia pubescens St. Hil. the seed development rate decreases. However, no significant differences were observed when the concentration was increased from 75 to $100 \%$, producing shoot length of 1.17 and $0.79 \mathrm{~cm}$, respectively.

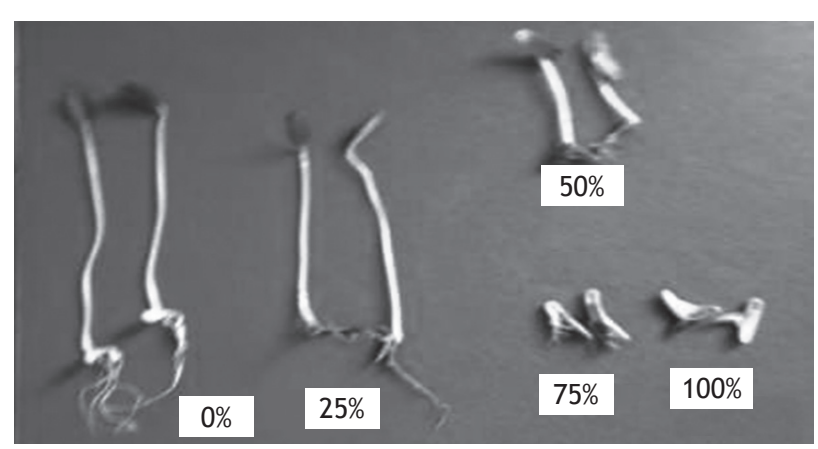

Figure 2 - Magonia pubescens St. Hil. gel effects in the development of aerial shoots in Cucumis sativus L. Source: Research data 


\section{Conclusion}

The results show that the hydrophilic gel of Magonia pubescens St. Hil. did not inhibit germination, but it demonstrates the effect on cucumber germination average speed and seedlings development. The effect is more effective at higher concentrations of Tingui. The seeds treated with $25 \%$ of Tingui concentration confirmed no significant differences from the control, therefore, it was verified that the concentration of $25 \%$ or less can be applied to seed pelleting process in future studies.

\section{References}

1. Harborne JB. Biochemical Interactions between Higher Plants. In: Harborne JB. Introduction to Ecological Biochemistry. London: Elsevier Academic Press; 1988. p. 243-63.

2. Oliveira SCC, Ferreira AG, Borgetthi F. Efeito alelopático de folhas de Solanum lycocarpum A. St. Hil. (Solanaceae) na germinação e crescimento de Sesamum indicum L. (Pedaliaceae) sob diferentes temperaturas. Acta Bot Bras. 2004;18(3):401-6.

3. Teixeira AZA, Pinto LR, Gomes MWF, Alves MC, Rigonato VD. Evaluation and comparative study of pre-formulations properties from the second layer of Tingui (Magonia pubescens St. Hill.) seed to several excipients. Simpósio Internacional Sobre Saberes Tradicionais, Biodiversidade, Biotecnologia e Dinâmicas Territoriais - SINBIOTEK, Nov 2010, Goiânia, Brasil.

4. Rigonato VD, Teixeira AZA. Use and abuse of Savanna Biodiversity: the (re) signification of socio-cultural values of traditional populations. Simpósio Internacional Sobre Saberes Tradicionais, Biodiversidade, Biotecnologia e Dinâmicas Territoriais - SINBIOTEK, Nov 2010, Goiânia, Brasil.

5. Brasil. Decreto n. 4.339, de 22 de agosto de 2002. Institui princípios e diretrizes para a implementação da Política Nacional da Biodiversidade. Diário Oficial [da] República Federativa do Brasil, Poder Legislativo, Brasília, DF, 22 ago. 2002. [acesso 25 jun. 2011]. Disponível em: www.presidencia.gov.br.

6. Zaidan LBP, Carreira RC. Seed germination in Cerrado Species. Braz J Plant Physiol. 2008;20(3):167-81.
7. Manoel DD, Doiche CFR, Ferrari TB, Ferreira G. Atividade alelopática dos extratos fresco e seco de folhas de barbatimão (Stryphnodendron adstringens (Mart.) Coville) e pata-de-vaca (Bauhinia forficata link) sobre a germinação e desenvolvimento inicial de plântulas de tomate. Semina. 2009;30(1):63-70.

8. Barreiro AP, Delachiave MEA, Souza F. Efeito alelopático de extratos de parte aérea de barbatimão [Stryphnodendron adstringens (Mart.)Coville] na germinação e desenvolvimento da plântula de pepino. Rev Bras Pl Med. 2005;8(1):4-8.

9. Belz RG. Allelopaty in crop/weed interactions - an update. Pest Manag Sci. 2007;63(4):308-26.

10. Oliveira AS, Silva MS, Rabello AR, Vieira EA, Lima TR, Espíndola LS, et al. Planta nativa do Cerrado, gênero magonia, da família do guaraná (Sapindaceae), possui princípios ativos contra o crescimento micelial in vitro de fungos fitopatogênicos. IX Simpósio Nacional Cerrado e II Simpósio Internacional Savanas, Brasília, 2008.

11. Franzin SM, Meneses NL, Garcia DC, Roversi T. Avaliação do vigor de sementes de alface nuas e peletizadas. Rev Bras Sementes. 2004;26(2):114-8.

12. Gorin PAJ, Teixeira AZA, Travassos LR, Labouriau MLS, Iacomini M. Characterization of carbohydrate components of an unusual hydrogel formed by seed coats of Magonia pubescens (Tingui). Carbohy Res. 1996;282:325-33.

13. Joly, CA, Felippe GM, Dietrich SM, Campos-Takaki GM. Physiology of germination and seed gel analysis in two populations of Magonia pubescens St Hil. B J Bot. 1980;3:1-9.

14. Labouriau MLS. A semente de Magonia pubescens St. Hil. Morfologia e germinação. An Acad Bras Ciênc. 1973;45:501-36.

15. Teixeira AZA. Compaction characteristic of the powder from the seed coat of tingui (Magonia pubescens). Est Biol. 2007;29(68/69):277-82.

16. Teixeira AZA. Evaluation of powder properties from the seed coat of Tingui (Magonia pubescens) as an excipient for seed pelleting. Est Biol. 2007;29(67):171-8.

17. US Environmental Protection Agency - US EPA. Seed germination/root elongation toxicity test. EG-I2, Office of Toxic Substances, Washington DC, 1982. 
18. US Food and Drug Administration - USFDA. Seed germination and root elongation. FDA Environmental Assessment Technical Guide n. 4. 06. Center for Food Safety and Applied Nutrition and Center for Veterinary Medicine, US Department of Health and Human Services, Washington DC, 1987.

19. Organization for Economic Cooperation and Development - OECD. Terrestrial plants: OECD Guideline for Testing of Chemicals. 1984. n. 2/8.
20. Wang X, Sun C, Gao S, Wang L, Shuokui H. Validation of germination rate and root elongation as indicator to assess phytotoxicity with Cucumis sativus. Chemosphere. 2001;44:1711-21. 